GLOBAL JOURNAL OF SOCIAL SCIENCES VOL 15, 2016: 13-25

COPYRIGHT@ BACHUDO SCIENCE CO. LTD PRINTED IN NIGERIA. ISSN 1596-6216

\title{
REAL EXCHANGE RATE MISALIGNMENT AND ECONOMIC PERFORMANCE IN NIGERIA
}

\section{ENANG UDAH AND FERDINAND ITE}

(Received 24 March 2016; Revision Accepted 25 May 2016)

\begin{abstract}
The objective of the study had been to investigate the impact of real exchange rate misalignment on economic growth in Nigeria. This paper adopted purchasing power parity index, the parallel market index and the model-based index of exchange rate misalignment to investigate the effects of real exchange rate misalignment on economic performance in Nigeria. The results revealed that only the index of real rate of exchange purchasing power parity was positively related to per capita GDP. Parallel market index and model-based index were inversely related to per capita GDP. The explanatory powers of the estimated results were good with high speed of adjustments indicating that the variables were cointegrated. The paper recommends that improving the terms of trade and per capita income will ameliorates exchange rate misalignment.
\end{abstract}

KEYWORDS:Exchange rate misalignment,co-integration and economic growth.

\section{INTRODUCTION}

Real exchange rate misalignment and economic performance has continued to gain currency in recent policy debates. This is because exchange rate misalignment may result in undesirable economic performance. Exchange rate misalignments in the fixed and adjustable exchange rate regimes are a reflection of poor policy fundamentals that prevent exchange rates from adjusting to desired macro-economic threshold of policy. In a floating exchange rate policy, misalignments are primarily caused by variables that change the rate of exchange excessively relative to some economic rules and principles governing the price system.

Consistent shocks and volatility in the external real rate of exchange fluctuations could have negative impact on macroeconomic variables. One major negative effect is on domestic and foreign investment and this can influence capital accumulation. Another influence is on tradable sector, by influencing its competitiveness in comparison with the rest of the world (Ndavi, 2012).

This paper is motivated by the need to provide more information on the effect real rate of exchange misalignment would have on economic performance of Nigeria. This is because the debates on the impact of exchange rate misalignment on economic performance are not conclusive. The objective of this paper is to investigate the effect of exchange rate misalignment on per capita GDP and terms of trade in Nigeria.

The specific objectives are to investigate the impact of purchasing power parity, parallel market index and model-based index of real

Enang Udah, Department of Economics, University of Calabar, Calabar, Cross River State, Nigeria.

Ferdinand Ite, Department of Economics, University of Calabar, Calabar, Cross River State, Nigeria. 
exchange rate misalignment on per capita income, terms of trade and oil price volatility in Nigeria.

\section{LITERATURE REVIEW}

Hooper and Mann (1989) and BlundellWagnall and Brown (1991) used structural model to investigate the real rate of exchange determination nexus. Their results showed distortions as the major cause of exchange rate misalignment. Stryker (1990) applied the purchasing power parity model to agricultural export products in Ghana via equilibrium rate of exchange determination. The estimates of the real foreign exchange rates when compared with the official rates in the study period showed that over -valuation of the rate of currency exchange is linked to monetary expansion programmes- a scenario which culminated in uncontrollable and persistent rise in the general price levels. Nevertheless using arbitrary base year period, Stryker's (1990) findings collaborates the findings of Edwards (1989) who opined that exchange rate over-valuation is a product of expansionary fiscal and monetary policy measures.

Aron and Ayogu (1995) and Soludo and Adenikinju (1997) investigated equilibrium exchange rate determination using the errorcorrection methodology. Soludo and Adenikinju (1997) used the co-integration method in determining real rate of exchange equilibrium using Nigeria as a case study. Calculating volatility values they discovered that there was negative effect of misalignment series on manufacturing sector investment in Nigeria.

Elbadawi and Soto (1995) calculated real exchange rate for developing countries such as Burkina-Faso, Coted'Ivoire and Chile, four SubSaharan countries and three other less developed nations by applying the co-integration error correction mechanism (ECM). The result revealed that the stationary values of the different fundamentals were significantly correlated with the equilibrium real exchange rate (ERER) and that the former level of sustainability highly depended on the value of the latter.

Odedukun (1997) researched on 38 groups of African nations, by investigating the effects of macroeconomic policies, currency reduction and fundamental movement in real exchange rate. He revealed that government fiscal deficit spending, rise in domestic credit, and the ratio of GDP to domestic absorption, government consumption to GDP ratio, improvement in export-import ratio, per capita GDP as well as parallel market rate of exchange premium. led to increment in the real rate of exchange. Conversely, the rate of consumerwholesale price in trading partners countries, the ratio of investment to GDP and the frequency of devaluation and advanced nations economic growth culminate in the reduction in real rate of exchange. Studies by Hsieh (1982), Marston (1987), and Edison and Wovland (1987) revealed that differences in productivity levels leads to the Balassa-Samuelson effect. The works of Patel and Srivastava (1997) revealed that the overall deficit in government spending, GDP-investment ratio and the rate of nominal exchange were the main factors that impacts on real exchange rate in India within the time under consideration.

The econometric investigation of Aron, Elbadawi and Khan (1997) are not only interesting but emphatically fascinating. The paper showed that foreign inflows of assets and reserves bring about appreciation in the rate of exchange; volume of trade expansion, public spending, non-gold commodity terms of trade as well as real price of gold have both short-term and long-term impact on real exchange rate. Hence, further expansion in trade, weakened export-import ratio and reduction in the inflows of foreign assets into the nation result in the depreciation of the currency. Nevertheless, unsustainable public spending leads to exchange rate over-valuation.

Sub-Saharan Africa collaborative strength was examined by Ogunkola (2000) using a rather fascinating model predicating on propositions linking the three basic conditions of monetary union success with the real exchange rate, which are productive factor mobility, export trade expansion as well as the level of openness of the economy, he concluded that real exchange rate is mainly influenced by above identified factors.

Beatrice (2001) in Zambia used a technique of co-integration to ascertain the determination of real rate of exchange during long-term exports and imports trade, and of the real exchange rate in the domestic economy. The paper revealed that factors such as commodity trade terms, public sector consumption spending as well as share of investment determine real exchange rate for imported goods. Furthermore, commodity terms of trade, share of investment and real GDP growth rate as well as the apex 
bank reserves and taxes on trade have long term effect on real foreign exchange rate for exports. Furthermore it was discovered that terms of trade, share of investment, as well as the growth rate of real GDP have long-term impact on the internal real exchange rate. Also indices such as foreign aid and the level of openness impact on the real rate of exchange in the short term.

Macdonald and Ricci (2003) opined that commodity trade terms, different in real rate of interest, foreign net reserves, and GDP per capita have positive impact on exchange rate in South Africa. However, the rate of trade openness and general fiscal balances has inverse effect on real rate of exchange of the country. Annsofia-Peterson (2005) examined the parameters which influence exchange rate fluctuation in Sweden, Japan and United Kingdom against the United States dollar from 1995 to 2004. The estimates revealed that in the three countries, changes in exchange rate are highly statistically significant and mostly affected by rate of interest.

Nyong (2005) used co-integration, unit root test and error correction model to model the relations that exist between real exchange rate misalignment and economic growth in Nigeria. The paper showed that the purchasing power parity, parallel market and model-based indices of real exchange rate misalignment affect economic growth negatively.Obadan (2006) investigated the trend of exchange rate management and administration using Nigeria as a case study between 1986 and 2005, and taking macroeconomic fundamentals such as net export differentials, capital inflows and the various measures of misalignment discovered that the prolonged deviation of real rate of exchange from equilibrium has created oscillation in Nigeria economic growth.

Frankel (2007) discovered that there is a positively direct correlation between real exchange rate and commodity terms of trade, one year lagged value of real exchange rate and the real rate of interest. Obi, Obida and Nurudeen (2010) using co-integrating method and error correction approach to establish the correlation between some potential determinants of real exchange rate in Nigeria, realized that productivity differential, government consumption expenditure, investment and foreign exchange reserves affects exchange rate positively. Benigno and Thoenissen (2011) examines the effect of the exchange rate level and fluctuations on the trade balances in Chile and New Zealand and found out that reduction of exchange rate do not lead to a sizeable difference in the New Zealand trade balance but exchange rate fundamentals such as export volume, imports, investment and productivity differentials affect trade balance positively.

Bussiere, Saxena and Tovar (2012) investigated the variables that affects exchange rate fluctuation in Japan and discovered that real exchange rate is positively related to net export, real exchange rate differentials and one-year lagged of net exports.Karageikli, Bachetta and Van (2013) using a factor augmented vector auto-regression (FAVAR) approach to determine underlying exchange rate shocks and it effect on output in different industries in new Zealand. The FAAR approach permits the authors to ascertain the correlations between the rate of exchange and over three hundred New Zealand macroeconomic variables. The study affirms that the tradable/non-tradable aggregation of economic activities help to ascertain the relationship between the real rate in the economy with the exchange rate and hence showed that the largest negative impact from the exchange rate shock was peculiar in the construction and manufacturing industries.

Lopez, Tile and Bassiere (2014) investigating the connection between exchange rate appreciations and growth, and taking macroeconomic fundamentals such as productivity growth, capital inflows and shocks. It was found that exchange rate movement driven by shocks to financial market delivers an inefficient allocation and was negatively related with exchange rate. Productivity growth and capital inflows were empirically confirmed to be positively related to real exchange rate.

From the reviewed literatures it is apparent that none of these studies have attempted to capture the impacts of policy changes on real exchange rate misalignment in recent times, neither is there an attempt to evaluate the impact of oil price volatility on growth. Therefore, this study is an attempt to fill this gap.

\section{Theoretical framework}

The theoretical underpinnings for this paper are anchored on the Traditional flow model (TFM), Monetary Model of exchange rate determination (MD) and the Portfolio Balance Model (PBM). 
The traditional flow model (TFM) postulates that the exchange rate is determined by the interplay of the market forces of demand and supply for foreign exchange. The school holds that exchange rate is in equilibrium when supply equals demand. Misalignment in the exchange rate is translated into imbalance in the current account. The current account is said to be determined by three main factors; relative prices, real income, and interest rate. TFM postulates that domestic price increase relative to foreign prices lead to exchange rate depreciation because increase in domestic prices feed into costs thereby making exports costly and highly uncompetitive. Consequently the supply of foreign exchange is highly constrained. On the other hand, import demand increases since imports become less expensive than exports.

Similarly, an increment in real output leads to a reduction in the value of foreign exchange rate because such increment tend to stimulate imports demand. On interest rate, the theory posits that an improvement in internal rate of interest vis-a-vis foreign interest rate causes an upward movement of the exchange rate via induced capital inflow. The model prescribes that a country that tends to strengthen its exchange rate must raise interest rate, lower prices, and reduce real growth. A country's current account surplus is financed by acquisition of foreign assets (outflow of capital) while a deficit is financed by inflow of foreign capital.

One the major criticism of the TFM is that it neglects asset market. A country cannot continue to run a current account deficit indefinitely and finance such deficit through capital inflow induced by higher interest rates. It assumes that foreigners will continue to invest in the domestic economy indefinitely. It fails to establish the stability condition for foreign acquisition of financial assets and ignores non-economic factor such as socio-political uncertainty which influence foreign capital inflow.

The monetary approach of exchange rate (MM) attempts to highlight variations in the rate of exchange in terms of fluctuation in the supply and demand of money between two countries. This approach argues that an upward movement in the supply of money causes the rate of exchange to plummet as a result of the induced inflationary pressures. An appreciation in real income given a fixed rate of nominal money supply caused prices to plummet leading to an appreciation of the exchange rate. When there is an appreciation in the domestic rate vis-a-vis the foreign interest rate it will lower money demand, raises prices (with given stock of money). The exchange rate depreciates as a result of the increase in relative prices.

The monetary model of exchange rate combines the quantity theory of money (or demand for money) with the purchasing power parity (PPP) hypothesis to identify the causal factors affecting the level of exchange rate.The rate of local currency depreciates as a result of domestic money supply vis-à-vis the foreign money supply ceteris paribus; the volume of money supply equally appreciates as a result of an increase in domestic real income or productivity relative to foreign productivity and the rate of currency exchange depreciates as a result of an appreciation in the domestic rate of interest relative to foreign interest rate.

A comparison of the predictions of the TFM and monetary model (MM) indicates that although both specify the same factors, an upward movement in real income in the TFM leads to a fall (decrease) in the exchange rate but leads to an increase of the exchange rate in the MM. Similarly, an increase in domestic interest rate in the home country relative to foreign interest rate leads to appreciation of the exchange rate under the traditional flow model but to a depreciation in the monetary model.

An important weakness of the monetary approach is the postulation that there is perfect substitutability between domestic and foreign bonds. If they are not, their differences must be accounted for. This limitation is remedied by the portfolio balance model.

The Asset - Disturbance Model or Portfolio Balance Model (PBM) encompasses both the monetary model and another component called portfolio, where portfolio is usually captured by bonds. The PBM assumes that there are three forms of assets, monetary base (MB), domestic bonds (DB), and Foreign Bonds (FB) which economic agents may hold in their portfolio. It posits that the rate of exchange is in equilibrium if the holding of these assets are in their desired proportion. An increase in domestic wealth may 
arise either from increases in the monetary base, holding of government bonds, or from current account surplus (foreign bonds).

An increase in the foreign bonds or assets demand results to a reduction of the rate of currency exchange, as a result of capital outflow; an increase in the holding of government bonds by the private sector drives the bond price down (income effect), rise interest rate (substitution effect) and cause an increase in the value of the exchange rate. Thus an increase in the holding of government bonds by the private sector has an uncertain effect on the exchange rate. The net change depends on the stronger of the two substitution effect or income effect. The exchange rate will appreciate if the substitution effect dominates and depreciates if the income effect dominates the substitution effect.

Two main criticisms of the PMB are its inability to determine the desired proportion in the holding of three forms of assets to establish the equilibrium exchange rate, and its neglect of the critical determinants of trade as well as the role of expectations. These are remedied by the purchasing power parity theory. The purchasing power parity hypothesis made provision for a reference guide to what the exchange rate should be. The model posits that the same bundle of goods in all nations involving in international trade should be purchased using the same unit of currency. This assumption can also be termed the Law of One Price. The absolute PPP theory assumes that the exchange rate between the currencies of any two nations should equal the ratio of the general price level in the two comparative economies.

Thus, the rate of exchange adjusts to the ratio of the domestic price level to foreign price level. The price level is assumed to be defined over the same basket of goods, and the purchasing power may be justified by assuming that arbitrage will equalize the prices of goods between them. The absolute PPP hypothesis is difficult to operate because price data are usually available in the form of price indexes of respective countries. For example the consumer price index or the GDP deflator is price index constructed on the basis of a particular year taken as a base year. To overcome this problem, the relative PPP is used. Other assumptions of PPP are that the goods to be traded or purchased are identical, and that there are no transaction costs or inflow of capital. There are two more assumptions namely the existence of full employment and price flexibility. An implication of the absolute purchasing power parity theory is that an increase of $x$ percent of the price of bundle of commodities in country $A$ relative to the price of the same bundle in country $B$ will result in $X$ percent reduction in the exchange rate of the country.

Relative purchasing power parity model which is an advancement of the absolute PPP theory states that changes in exchange rate between two nations should be equal to percentage changes in the ratio of price indexes of the comparative nations. The PPP theory is a long run proposition and is not applicable in the short term due to the simple reason that it takes time for price to adjust fully. A cardinal principle of relative purchasing power parity theory is that if tastes do change over time in the trading countries, then the theory predicts the change in the exchange rate between two consecutive time periods.

In the absolute version of PPP, if E>1, the currency of the domestic economy should depreciate (i.e.) should fall) relative to the foreign currency. However, if $\mathrm{E}<1$, the domestic currency should appreciate (i.e. rise) relative to the foreign currency. The relative version of PPP theory focuses on variability of inflation as the dominant determinant of exchange rate instability. It suggests the need for co-ordination of monetary and fiscal policies to control inflation. By targeting inflation, exchange rate problems may be addressed. If two countries produce the same goods, all the commodities are tradable and there are no hindrances to international trade, then PPP would be strict application of the Law of one price.

Attempts have been made in the past to summarize some of the inherent weaknesses of PPP theory. The identified weaknesses include:

(i) It is difficult to determine the appropriate base period. Different base period provide different PPP exchange rates.

(ii) There are various price indexes consumer price indexes or gross domestic product deflator. For instance the use of consumer price index would place heavy weights on consumables 
whereas the use of GDP deflator would place heavy weight on non-tradable.

(iii) The equilibrium exchange rate may change for structural reason and this may complicate the estimation of the exchange rate.

(iv) PPP requires projections of prices for one to two years ahead.

(v) Price indexes of different countries do not reflect the true changes in purchasing power

(vi) Tariffs exchange rate restrictions, quotas, etc. may distort the demand and supply conditions.

(vii) The PPP applies to the long - run and not to the short run.

Several empirical studies have been carried out to establish the correlation between economic performance and long term disequilibrium or misalignment in real exchange rate in many less developed countries and the transition economies of Central and Eastern Europe in recent times. Overvaluation of foreign exchange rates has negatively affected many developing countries, including Nigeria. The locative nature of resources in any country is often affected by the consistent fluctuation in the real rate of exchange. An appreciation in the Nigerian real exchange rate will make goods produced locally dearer and will encourage consumers to substitute less expensive traded goods for home goods. This is not normal for a small evolving economy like Nigeria. More so, Nyong (2005) and Obadan (2006) have shown an inverse correlation between real exchange rate misalignment and economic growth in Nigeria.

\section{Methodology}

This paper used the descriptive as well as cointegration and error correction methods. The framework for the study has its basis on the purchasing power parity, parallel market and model-based indexes of exchange rate misalignment in Nigeria.

Hence, the research was predicated on the construction of the index of exchange rate misalignment by adopting the following approaches.

- The parallel market exchange rate premium (PMP) approach based on Edwards (1989, and Obadan (2006).
- The model based index of exchange rate misalignment (Edward 1989; Ghura\& Grennes, 1993), Chinn (1999) and Mordi (2006).

The paper adopted three measures of exchange rate misalignment namely, Purchasing Power Parity of exchange rate misalignment (MISRt), Model-Based exchange rate misalignment (MMIS) as well as the parallel market index of exchange rate (PMPt). In the purchasing power parity if MISRt 0 , under devaluation and MISRt 0, overvaluation. The weakness of this index is that it cannot capture "changes in economic fundamentals and domestic macroeconomic, trade and exchange rate policies on the equilibrium" real exchange rate. The model based index of real exchange rate misalignment (MMIS) is a little more complicated. It is predicated on the regression estimates of the determinants of real exchange rate.Parallel market index of real rate of exchange misalignment (PMPt) is the parallel market premium expressed as a percentage of the nominal rate of exchange. The PMPt is an attempt to remedy some of the short comings of MISR based on PPP. It captures not only the misalignment in the exchange rate, but also distortions in the external exchange market and the extent of exchange management and import allocation in the domestic economic system.

\section{Model Specification}

To ascertain the effects of real exchange rate on economic growth, we have specified an exchange rate misalignment and growth equation as follows:

\section{A) PPP Index of Real Exchange Rate Misalignment}

PCGDPR = $f$ (MISR, TOT, EDTX, GDIY, LABF, OPV)

The structural equation is specified thus: PCGDPR $=\alpha_{0}+\alpha_{1}$ MISR $+\alpha_{2}$ TOT $+\alpha_{3}$ EDTX $+\alpha_{4}$ GDI $\mathrm{Y}+\alpha_{5} \mathrm{LABF}+\alpha_{6} \mathrm{OPV}+\mathrm{Ut}$ 4.2

The a priori expectation for the above model is summarized as follows:

$\alpha_{1}, \alpha_{3}, \alpha_{6},<0$ and $\alpha_{2}, \alpha_{4}, \alpha_{5}>0$

B) Parallel Market Index of Real Exchange Rate Misalignments

PCGDPR = $\mathrm{f}$ (PMPt, TOT, EDTX, GDIY, LABF, OPV) 
The structural equation for the second model is specified thus:

PCGDPR $=b_{0}+b_{1} P M P+b_{2}$ TOT $+b_{3} E D T X+b_{4} G D I Y+$

$b_{5} \mathrm{LABF}+\mathrm{b}_{6} \mathrm{OPV}+\mathrm{Ut}-$

4.4

The a priori expectation for the second model is as follow:

$b_{1}, b_{3} b_{6}<0$ and $b_{2}, b_{4}, b_{5}>0$

C) Model-Based Index of Real Exchange Rate Misalignment

PCGDPR = $f($ MMIS, TOT, EDTX, GDIY, LABF, OPV)

The structural equation is specified thus:

PCGDPR $=b_{0}+b_{1}$ MMIS $+b_{2}$ TOT $+b_{3}$ EDTX $+b_{4}$ GDI

$\mathrm{Y}+\mathrm{b}_{5} \mathrm{LABF}+\mathrm{b}_{6} \mathrm{OPV}+\mathrm{Ut}$

4.6

The a priori expectation for the third model is $b_{1}$, $b_{3}, b_{6}<0$ and $b_{2}, b_{4}, b_{5}>0$.

\section{DISCUSSION OF VARIABLES}

$\mathbf{P C G D P R}=$ per capita GDP growth rate; this is the difference between GDP growth rate and population growth rate.

TOT $=$ Terms of trade: Commodity terms of trade expressing the export-import price ratio.

EDTX = External debt burden which measures the ratio of external debt to export unit price plus import unit price capturing debt overhang thesis.

GDIY = Gross domestic investment to GDP ratio.

LABF = Labour force: This captures the growth in labour force over the years.

$\mathrm{OPV}=$ volatility in the prices of oil indicating the fluctuation in the prices of petroleum in the international market.

\section{PRESENTATION OF EMPIRICAL RESULTS}

The results of the unit root test and error correction model are summarized in tables 5.1 and 5.2 respectively. The unit root result showed that the series are integrated of order one I(1). Having established whether or not the series are stationary or not, we proceed to estimate the error correction model of the purchasing power parity index of real rate of exchange misalignment, the parallel market index of real rate of exchange misalignment and the modelbased index of real rate of exchange misalignment. Note that the over parameterized model at this juncture is cumbersome to interpret in any meaningful perspective, the peculiar and basic role is to enable us to know and signify the main dynamic patterns of the parsimonious function that is more interpretable as well as more suitable for policy formulation.

Table 5.1: Unit Root Result (Augmented Dickey Fuller)

\begin{tabular}{|l|l|l|}
\hline Variable & Trend and Constant & Decision \\
\hline LRER & -5.069853 & $\mathrm{I}(1)$ \\
\hline TOT & -3.806579 & $\mathrm{I}(1)$ \\
\hline CLOSE & -6.913550 & $\mathrm{I}(1)$ \\
\hline FDI & -6.475911 & $\mathrm{I}(1)$ \\
\hline EXDOMCR & -6.472987 & $\mathrm{I}(1)$ \\
\hline GDPGR & -5.005463 & $\mathrm{I}(1)$ \\
\hline LNER & -5.206156 & $\mathrm{I}(1)$ \\
\hline EDTEX & -5.519259 & $\mathrm{I}(1)$ \\
\hline INF & -4.453385 & $\mathrm{I}(1)$ \\
\hline PCGDPR & -5.328762 & $\mathrm{I}(1)$ \\
\hline GDIY & -6.475911 & $\mathrm{I}(1)$ \\
\hline LLABF & -6.568908 & $\mathrm{I}(1)$ \\
\hline OPV & -9.435458 & $\mathrm{I}(1)$ \\
\hline MISR & -7.834294 & $\mathrm{I}(1)$ \\
\hline
\end{tabular}

Critical Values:

$1 \%$ level $=-3.596616$

$5 \%$ Level $=-2.933158$

$10 \%$ level=-2.604867 
Table 5.1: Summary of parsimonious error correction results

\begin{tabular}{|l|l|l|l|}
\hline Variables & $\begin{array}{l}\text { Purchasing Power } \\
\text { Parity (MISRt) }\end{array}$ & $\begin{array}{l}\text { Parallel Market index } \\
\text { (PMPt) }\end{array}$ & $\begin{array}{l}\text { Model Based Index } \\
\text { MMIS) }\end{array}$ \\
\hline C & $0.044179(4.12)$ & $-0.2730363(-0.07)$ & $-0.097727(-0.07)$ \\
\hline PCGDPR (-1) & $1.887616(4.63)$ & $0.915850(2.29)$ & $0.943820(3.16)$ \\
\hline TOT & $-0.440112(-3.81)$ & $0.045789(-2.29)$ & $-0.054279(2.14)$ \\
\hline TOT(-1) & $0.202718(1.83)$ & $0.049009(1.79)$ & $0.054279(2.14)$ \\
\hline DOPV & $0.172714(1.50)$ & $0.098873(1.78)$ & $0.101213(1.89)$ \\
\hline DMISRt & $5.088949(0.90)$ & & \\
\hline ECM1 & $-0.788245(-3.57)$ & & \\
\hline GDIY(-1) & & $0.066784(-1.14)$ & \\
\hline PMP & & $-0.024440(-141)$ & \\
\hline PMP(-1) & & $-0.0232280(1.55)$ & \\
\hline ECM2 & & & $-2.995059(-3.18)$ \\
\hline DMMIS & & 0.55 & $-0.970735(-3.45)$ \\
\hline ECM3(-1) & & 1.7 & 0.51 \\
\hline$R^{2}$ & 0.53 & 2.0 & \\
\hline D.W & 2.08 & & \\
\hline
\end{tabular}

Note: values in parenthesis are the t-statistics

Table 5.2presents the estimated results of the parsimonious model for Purchasing Power Parity (MISRt), Parallel Market Index (PMPt) and Model Based Index (MMIS). The MISRt results, showed that one year lagged per capita income (PCGDPR(-1)), terms of trade (TOT(-1)) and oil price volatility (DOPV) conformed to a priori expectations and were statistically significant. This implies that one per cent increase in PCGDPR(-1) and TOT(-1) will result in 1.9 and 0.2 per cent increase in exchange rate appreciation. The error correction term is significant and negatively signed. This implies that the real exchange rate adjust negatively to disequilibrium in the co-integrating vector (about 8 per cent in a year). This also confirmed the long-run property of the model. The Durbin Watson statistics value of 2.08 shows no first order serial correlation and the adjusted $R^{2}$ shows a good fit. The value of $R^{2}$ showed that 53 per cent of total variation around the mean is explained by the repressors'.

Akaike (AIC), Schwarz (SIC) and Hannan-Quin criteria can be used to compare insample and out-sample forecasting performance of a model. In this comparison, AIC and SIC with the lowest value is preferred and also imposes a penalty for adding regressors to the model. These arguments are not the focus in our paper. However, in the case of our paper and as noted by Gujarati, (2003) and Patterson, (2000) these information criteria is joined by the requirement that the resulting model has residuals which are consistent with a lack of serial correlation. Thus from our results the three models showed no evidence of serial correlation, therefore we placed inference based on the Durbin Watson statistics rather than on AIC or SIC.

The Parallel Market Index model (PMPt) results was also satisfactory. As shown in table 5.2 , one year lagged per capita income, terms of trade both lagged and levels as well as price volatility conformed to a priori expectations and were statistically significant. This suggests that real depreciation of exchange rate helps real per capita income and one per cent decrease (depreciation) in misalignment can increase per capita income by 9 per cent and terms of trade by 0.04 per cent. The error correction variable was not only significant but was negatively signed. The high speed of adjustment of exchange rate to disequilibrium in the error correction vector of 99 per cent within a year is satisfactory. The Durbin Watson statistics was approximately two, indicating the absence of serial correlation. The model based index results shows a good fit with adjusted R2 of 0.51 and absence of serial correlation. Variables of interest were statistically significant and conformed to a priori expectations.

\subsection{Summary and conclusion}

This paper used purchasing power parity index, the parallel market index and the model-based 
index of exchange rate misalignment to investigate the effects of real exchange rate misalignment on economic performance in Nigeria. The results revealed that only the index of purchasing power parity was found to be positively related to per capita GDP while the parallel market index and model-based index were inversely related to per capita GDP. This corroborates with the works of Nyong (2005) and Obadan (2006), who asserts that long-term inverse relationship exist between real rate of exchange misalignment and economic growth in Nigeria. This strongly suggests that exchange rate misalignment over the years has been distortionary. The outcome of the results also showed that per capita income and terms of trade were significant and correctly signed.Any terms of trade improvement result in significant appreciation of the real exchange rate.

\section{CONCLUSION}

Within both developing and developed economies, exchange rate management plays a very important role in economic performance and hence serves as a nominal anchor for the determination of both domestic and foreign trade balance. Therefore, the need for effective rate of exchange management need not be overstressed. The paper set out to investigate the effects of real rate of exchange misalignment on economic performance in Nigeria and the findings suggests that to improve terms of trade and per capita GDP, the country need to pursue exchange rate reforms that will reduce misalignment.The paper recommends that improving terms of trade and per capita GDP could reduce exchange rate misalignment.

\section{REFERENCES}

Annsofia, P., 2005. Identifying the determinants of exchange rate movements: Evaluating the real interest differential model. Cited at http://urn.kb.se/resolves? Urn: nbn: se: hj: diva-247.

Aron, C and Ayogu, M., 1995. The effects of real exchange rate uncertainty on export: Empirical evidence. The World Bank Economic Review, 3, (2):

Beatrice, K. M., 2001.Long-run and short-run determinants of the real exchange rate in
Zambia.Working papers No 40. cited at http://www.handels.gu.se/econ/.

Benigno, $\mathrm{G}$ and Thoenissen C., 2011.Equilibrium exchange rates and supply-side performance.The Economic Journal, 113(486), C 103-C 127.

Blundell-Wignall, A. and Browne, K. C., 1991. Exchange rate volatility and world trade European Journal of Economics, Finance and Administrative Sciences.

Bussiere, M.,Saxena, S and Tovar, C., 2012. Chronicle of large currency devaluations: Re-examining the effects on output. Journal of International Money and Finance, 31, (4):

Chinn, M., 1999.Measuring misalignment: Purchasing Power Parity and East Asian currencies in the 1990s.IMF Working paper (120), 1-29.

Edison, $\mathrm{H}$ and Wovland, J., 1987.A quantitative re-assessment of the purchasing power parity hypothesis: Evidence from Norway and the United Kingdom. Journal of Applied Economics, (4), 309-333.

Edwards, G., 1989. Real exchange rates devaluation and adjustment. The MIT Press, Cambridge, MA.

Elbadawi, I. A and Soto, R., 1995. Aid, real exchange rate misalignment and economic performance in Sub-Saharan Africa. Institute of Economics-PUC Working paper No.368.

Frankel, J., 2007.On the rand: Determinant of the South African exchange rate.CID Working paper No. 139.

Ghura, D andGrennes, T., 1993.The real exchange rate and macroeconomic performance in Sub-Saharan Africa. Journal of Development Economics, 42, 155-174.

Gujarati, D. N., 2003. Basic econometrics.Tata McGraw Hill

Hall, S. G and Henry, S. G. B., 1989. 
Macroeconomic modelling and contributions to economic analysis. (North-Holland, Amsterdam reprint.),416421.

Hopper, A. C and Mann, T., 1989. International trade and exchange rate volatility. European Economic Review 36, 13111321.

Hsieh, D., 1982.The determination of the real exchange rate: The productivity approach.Journal of International Economics, 12,355-362.

IMF., 2012. Working paper No. 7/296

Johansen, S., 1988.Statistical analysis of cointegrating vectors. Journal of Economic Dynamics and Control, 12, 231-254.

Johansen, S and Juselius, K., 1990.Maximum likelihood estimation and inference on co-integration with applications to the demand for money.Oxford Bulletin of Econometrics and Statistics, 52, 169210.

Karageikli, M., Bacchetta, P and Van, W., 2013. Non-fundamental shocks and exchange rate misalignment. The Treasury, 2, (3):

Lopez, C. Tile, C andBassiere, M., 2014. Do real exchange rate appreciations matter for growth? MARP Paper No. 54892.

MacDonald, R. \& L. Ricci (2003).Estimation of the equilibrium exchange rate for South Africa.IMF Working paper WP/03/44.

Makrelor, K., 2008. Determinants of the equilibrium exchange rate for South Africa's manufacturing sector and implications for competitiveness. Being a Draft of a Working paper of the national treasury of South Africa.Cited at htpp://www.treasury.gov.za.

Mordi, N. O., 2006. Real exchange rate volatility and economic management in Nigeria, in the dynamics of exchange rate in Nigeria.CBN Bullion, 30, (3): 17-25.
Ndavi, T. W., 2012.The effects of real exchange rate misalignment on economic growth: $A$ case study of Kenya. Unpublished Thesis, Nelson Mandela Metropolitan University.

Nyong, M.O., 2005.International economics: Theory, policy and applications. Calabar: Wusen Publishers Ltd.

Obadan, M. I., 2006. Overview of exchange rate management in Nigeria from 1986 to date, in the dynamics of exchange rate in Nigeria. CBN Bullion, 30, (3): 1-15.

Obadan, M.I., 2009. Exchange rate regimes for developing and emerging markets. A paper presented at the 3- day International Conference on Central Banking Financial Stability and Growth Organized by the CBN in Abuja, May 4.

Obi, B, Obida, W. G and Nurudeen, A., 2010. Determinants of exchange rate in Nigeria, 1970-2007: An empirical analysis.Indian Journal of Economics and Business.

Odedokun, M.D., 1997. An empirical analysis of the determinants of the real exchange rate in African countries. The Journal of International trade and Economic Development,6,63-82.Cited at htpp://ww w.informaworld.com/smpp/title-content=t 71372237.grdb=all.

Odusola, A., 2009.Economics of exchange rate management, in the dynamics of exchange rate in Nigeria. CBN Bullion, 30, (3): 38-43.

Ojameruaye, E.O., 1991. An application of the purchasing power parity to the determinationof the realistic exchange rate of the Nigerian currency.Nigeria Financial Review, 3, (4):

Patel, U. R and Srivastava, P., 1997.The real exchange rate in India: Determinants and targeting. Centre for Economic Performance Discussion paper No. 323. 
Patterson, K., 2000. Introduction to applied econometrics: A time series approach. Palgrave Macmillan

Phillips, P. C. B and Peron, P., 1988.Testing for a unit root in time series regression. Biometrica.

Soludo, C. C and Adenikinju, F. A., 1997. Exchange rate misalignment and investment in Nigeria. Paper presented to OECD Development Centre Paris.

Stryker, A. M., 1990. Determinants of real exchange rate: The purchasing power parity model. Journal of Development Economics, 42, (5):

Williamson, J., 1982.The exchange rate system: Policy analysis.International Economics 5, Washington, Institute of International Economics.
Yotopoulos, P. A and Sawada, Y., 2005. Exchange rate misalignment: $A$ new test of long runs PP-based on cross country data.CIRJE Discussion paper no. F 318, 1-23. 


\section{APPENDIX 1}

\section{Parsimonious Results for MISR}

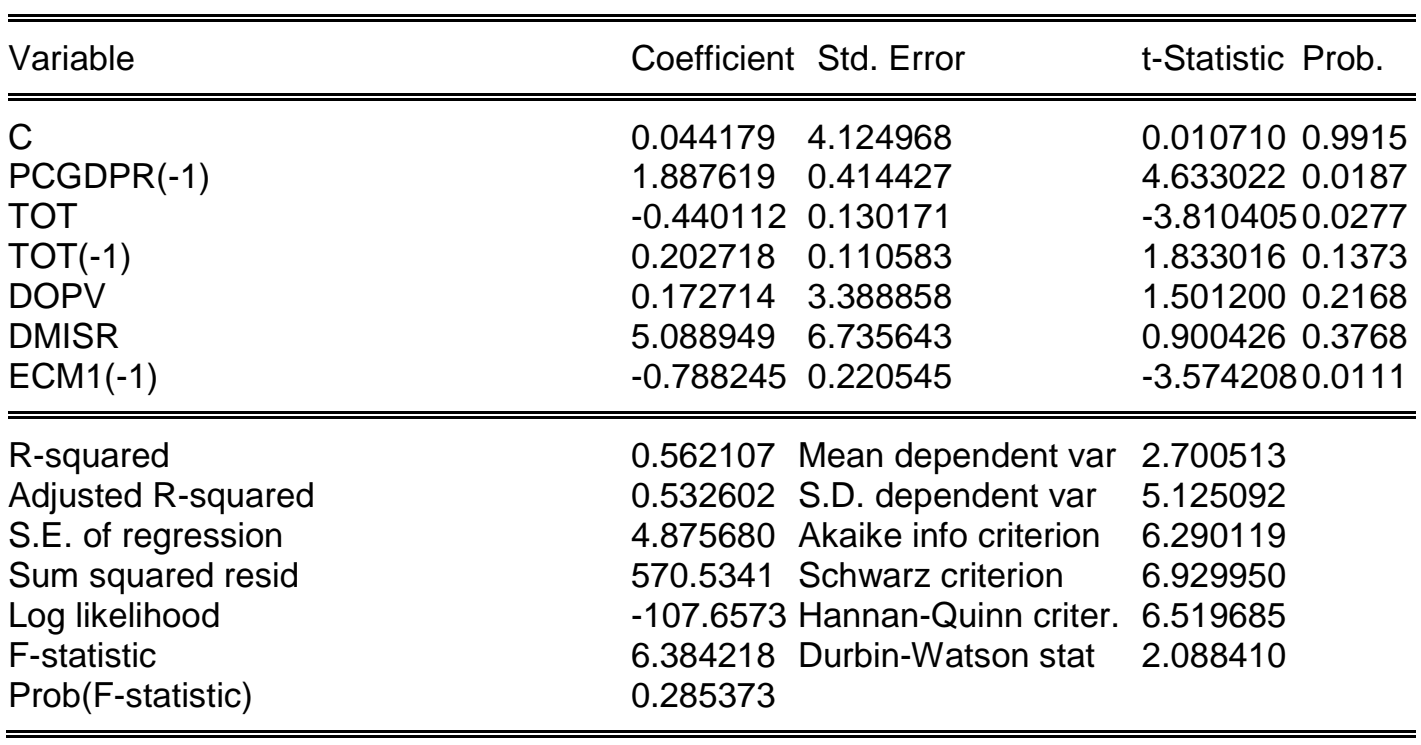

Parsimonious Results for PMP

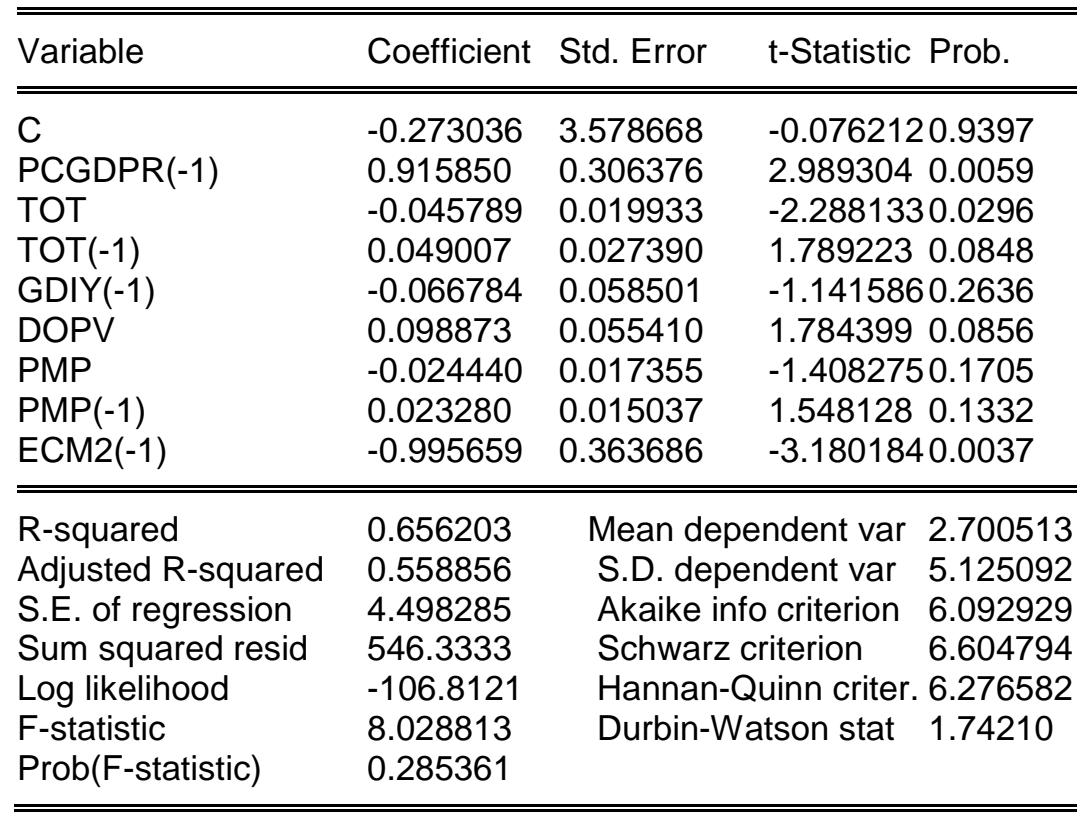




\section{Parsimonious Results for MMIS}

\begin{tabular}{lllll} 
Variable & Coefficient & Std. Error & t-Statistic & Prob. \\
\hline \hline C & -0.097727 & 3.383086 & -0.028887 & 0.9772 \\
PCGDPR(-1) & 0.943820 & 0.298747 & 3.159263 & 0.0038 \\
TOT & -0.056034 & 0.018093 & -3.097034 & 0.0044 \\
TOT(-1) & 0.054279 & 0.025342 & 2.141832 & 0.0410 \\
DOPV & 0.101213 & 0.053358 & 1.896848 & 0.0682 \\
DMMIS & -2.210819 & 3.128532 & -0.706663 & 0.4856 \\
ECM3(-1) & -0.970735 & 0.319734 & -3.452213 & 0.0018 \\
\hline \hline R-squared & 0.540534 & Mean dependent var & 2.700513 \\
Adjusted R-squared & 0.516202 & S.D. dependent var & 5.125092 \\
S.E. of regression & 4.383969 & Akaike info criterion & 6.026532 \\
Sum squared resid & 538.1373 & Schwarz criterion & 6.495741 \\
Log likelihood & -106.5174 & Hannan-Quinn criter. & 6.194880 \\
F-statistic & 7.393401 & Durbin-Watson stat & 2.008430 \\
Prob(F-statistic) & 0.033652 & & & \\
\hline \hline
\end{tabular}

